\title{
Effect of thermal spring water on human dendritic cell inflammatory response
}

This article was published in the following Dove Press journal:

Journal of Inflammation Research

\author{
Yoan Eliasse ${ }^{1,2}$ \\ Marie-Florence Galliano ${ }^{3}$ \\ Daniel Redoules 4 \\ Eric Espinosa ${ }^{1,2}$ \\ 'INSERM UI037, Centre de Recherche \\ en Cancérologie de Toulouse (CRCT), \\ Toulouse F-31037, France; ${ }^{2}$ Université \\ De Toulouse, Université Paul Sabatier, \\ Toulouse F-31062, France; ${ }^{3}$ Research and \\ Development, Pierre Fabre Dermo- \\ Cosmétique, Toulouse, France; ${ }^{4} \mathrm{Global}$ \\ Medical Direction, Laboratoire \\ Dermatologique Avène, Pierre Fabre \\ Dermo-Cosmétique, Toulouse, France
}

Correspondence: Eric Espinosa

INSERM UI037, CRCT, 2 Avenue Hubert

Curien CS 53717, 31037 Toulouse cedex

I, France

$\mathrm{Tel}+33582741770$

Email eric.espinosa@inserm.fr
Background: Hydrotherapy appears as a valuable therapeutic tool in the management of patients suffering from chronic skin inflammatory diseases. Nevertheless, the underlying immune mechanisms of these beneficial effects remain poorly understood. To better understand the biological effects of thermal spring water on the immune system, we investigated the effects of Avène thermal spring water (ASW) on dendritic cells as key cells participating in the control of the immune response.

Methods: Dendritic cells (DCs) were generated from human monocytes and matured with LPS in ASW-based culture medium or in dexamethasone supplemented culture medium as an anti-inflammatory treatment. The phenotypes and abilities of these DCs to produce cytokines and induce allogeneic $\mathrm{T}$ cell response was next assessed.

Results: We showed that ASW modulated the differentiation of monocytes into DCs and impacted the DC maturation upon LPS priming. We observed a reduction of the CD83, CD86, CD1a and HLA-DR molecule expression and a decrease of IL-12 and IL-23 production whereas IL-10 production was increased. LPS-primed DCs generated in presence of ASW exhibited a reduced capacity to induce naive $\mathrm{CD} 4^{+}$T cell proliferation and IFN- $\gamma$ and IL-17 production.

Conclusion: Our study showed that ASW is endowed with an immunomodulatory potential. ASW limits the DC stimulatory capacity of Th1 and Th17 cell responses by impairing their maturation, IL-12 and IL-23 production and accessory cell function.

Keywords: dendritic cells, hydrotherapy, inflammation, naive $\mathrm{CD}^{+} \mathrm{T}$ cells, dexamethasone

\section{Introduction}

Skin constitutes the first barrier and line of defense against pathogens and noxious substances. It is an immunologically active tissue with several resident immune cells and an important pool of recirculating lymphocytes. Due to its strategic location, skin is continuously exposed to a multitude of pathogens but also physical and chemical aggressions, which can lead to different types of inflammatory diseases. Spa therapy is widely used to treat inflammatory skin diseases, such as atopic dermatitis, psoriasis, rosacea, seborrheic dermatitis and others. ${ }^{1}$ The mechanisms underlying spa therapy are ill-understood and might incorporate chemical, thermal and immunomodulatory effects. ${ }^{2-4}$ Several studies showed that thermal spring waters decrease the pro-inflammatory abilities of keratinocytes. ${ }^{5-7}$ Avène thermal spring water (ASW) is commonly used in France to treat atopic dermatitis and psoriasis. Previous studies reported that ASW is endowed with an anti-inflammatory potential. ${ }^{7-9}$ Because dendritic cells (DCs) are key players in the control of the immune response, we investigated in this study the effects of ASW on human DCs. 
DCs are highly specialized antigen presenting cells (APCs), which are crucial for the induction and the control of immune responses. ${ }^{10,11}$ In steady state, DCs are sentinel cells equipped with a huge panel of pattern recognition receptors (PRRs) allowing them to detect virtually all pathogens or tissue damages. They are in an immature state, prone to antigen capture and with tolerance-inducing functionality. Upon PRR stimulation, DCs differentiate in a fully mature state, allowing them to migrate in secondary lymphoid organs and initiate adaptive responses. DCs activate antigen-specific $\mathrm{CD}^{+} \mathrm{T}$ cells by providing three main signals. ${ }^{12}$ During the maturation process, DCs upregulate cell surface expression of antigen presenting molecules such as MHC-class II and CD1 a molecules (signal 1) as well as $\mathrm{T}$ cell costimulatory molecules such as CD80 and CD86 (signal 2). ${ }^{13}$ Depending on the environmental cues detected and the PRR engaged, DCs drive T helper cell differentiation by producing cytokines (signal 3). ${ }^{14}$

Several groups of DCs reside in the skin in steady state; ${ }^{15,16}$ they control skin homeostasis and start immune responses. ${ }^{17}$ Moreover, upon inflammation, skin is infiltrated by myeloid DCs that are often referred to as inflammatory DCs. ${ }^{15,16,18}$ In chronic pathologies such as auto-immune diseases or allergy, these cells sustain a continuous activation of the adaptive immune system at sites of inflammation. ${ }^{19,20}$ Depending on the tissue microenvironment, Inflammatory DCs termed TipDCs (TNF- $\alpha /$ iNOS-producing DC) have been described in psoriasis ${ }^{21,22}$ or after bacterial infection. ${ }^{23}$ Inflammatory dendritic epidermal cells (IDECs) were described in atopic dermatitis. ${ }^{24}$ Inflammatory DCs are assumed to be monocyte derived, but their development is poorly known. ${ }^{15}$

DC maturation represents a key event in the immune response and is tightly controlled. Immature DCs are weak stimulators of $\mathrm{T}$ cell responses and are viewed as tolerogenic to ensure the maintenance of immune homeostasis. Tolerogenic DCs express low levels of costimulatory molecules and produce notably the immunomodulatory cytokine IL-10. ${ }^{25}$ Several clinical attempts were made to harness DC maturation in order to dampen the immune response in autoimmunity, graft rejection or chronic inflammatory diseases. ${ }^{17} \mathrm{~A}$ wide array of mediators such as IL-10, dexamethasone, vitamin D3 or rapamycin were used to induce a tolerogenic phenotype in DCs. ${ }^{26,27}$ In this study, we investigated the effects of ASW on DC maturation and functions. We used the classical model of DC derived from human monocytes in ASW-supplemented medium or in distilled water with or without dexamethasone-supplemented media as controls.

\section{Materials and methods}

\section{Spring water collection and processing}

ASW was collected in 2018 from the Avène thermal center (Laboratoire de l'Eau, Avène, France) using an aseptic procedure. Briefly, a single operator wearing sterile nitrile surgical gloves collected $2,000 \mathrm{~mL}$ water with a sterile $50 \mathrm{~mL}$ syringe. The water was filtered through $0.20-\mu \mathrm{m}$ pore cellulose nitrate membranes and stored at $4{ }^{\circ} \mathrm{C}$. All experiments were performed within 3 months of water filtration and storage. The hydrochemical analysis of ASW is provided in Table S1.

\section{Media}

RPMI-1640 powder (R6504 Sigma) supplemented with 2.0 g sodium bicarbonate $\mathrm{NaHCO}_{3}$ was reconstituted with Avène spring water or UltraPure ${ }^{\mathrm{TM}}$ DNase/RNaseFree Distilled Water (Invitrogen). Basal media were next supplemented with $10 \% \mathrm{FCS}, 1 \%$ penicillin $(10,000 \mathrm{U} /$ $\mathrm{mL})$ and streptomycin $(10 \mathrm{mg} / \mathrm{mL})$, Sodium pyruvate (1 mmol/L), HEPES (N-2-hydroxyethylpiperazine-N-2ethane sulfonic acid, $10 \mathrm{mmol} / \mathrm{L}$ ) all from GIBCO, the $\mathrm{pH}$ of the media was adjusted to 7.0 and the media were next sterilized immediately by filtration using a $0.22 \mu \mathrm{m}$ pore size unit. ASW-based complete RPMI medium was termed $\mathrm{R} 10_{\mathrm{ASW}}$, Ultrapure distilled water-based complete RPMI medium was termed $\mathrm{R} 10_{\mathrm{CTW}}$ and $\mathrm{R} 10_{\mathrm{CTW}}$ supplemented with $10^{-7} \mathrm{~mol} / \mathrm{L}$ dexamethasone (Sigma Aldrich) was termed R10

\section{Cell purification}

Peripheral blood mononuclear cells (PBMCs) were isolated from buffy coats (Etablissement Français du Sang) by Ficoll-Hypaque gradient centrifugation (specific gravity, $1.077 \mathrm{~g} / \mathrm{mL}$; Amersham Biosciences, USA) density. $\mathrm{CD} 14^{+}$cells were positively separated by anti-CD14 magnetic beads according to the Manufacturer's instructions (EasySep $^{\text {TM }}$ Human CD14 Positive Selection Kit II, Stemcell technologies). Isolated cells routinely contained more than $95 \%$ of $\mathrm{CD} 14^{+}$cells. Naive $\mathrm{CD} 4^{+} \mathrm{T}$ cells were isolated from PBMCs using EasySep ${ }^{\mathrm{TM}}$ Human Naïve $\mathrm{CD}^{+}{ }^{+} \mathrm{T}$ Cell Isolation Kit II (Stemcell technologies). The cell population obtained, contained $>95 \%$ of $\mathrm{CD}^{+} \mathrm{CD}^{+}$ $\mathrm{CD}^{2} 5 \mathrm{RA}^{+} \mathrm{CD}^{2} 5 \mathrm{RO}^{-}$cells, as assessed by flow cytometry.

\section{Generation and culture of MoDCs}

Purified $\mathrm{CD} 14^{+}$monocytes were seeded at $5 \times 10^{5}$ cells per well of a 12 -well plate in $2 \mathrm{~mL}$ of $\mathrm{R} 10_{\mathrm{ASW}}$ or $\mathrm{R} 10_{\mathrm{CTW}}$ or 
R10 ${ }_{\text {DEX }}$ supplemented with GM-CSF (500 IU/mL) and IL-4 (10 ng/mL) (both from PeproTech, Rocky Hill, NJ) and cultured for 5 days at $37^{\circ} \mathrm{C}, 5 \% \mathrm{CO}_{2}$. Half of the medium was replaced on Day 3. Non-adherent cells (immature DC) were collected at day 5 and analyzed by flow cytometry to assess CD11c expression; only cultures with more than $90 \% \mathrm{CD} 11 \mathrm{c}^{+}$ cells were used for experiments. Cells $\left(1 \times 10^{5}\right.$ per well in a Ubottom 96 plate) were next matured with $100 \mathrm{ng} / \mathrm{mL}$ LPS (Ultrapure LPS from E. coli 055:B5, Invivogen, France) for 2 additional days, in their respective media: $\mathrm{R} 10_{\mathrm{ASW}}, \mathrm{R} 10_{\mathrm{CTW}}$ or R10 $10_{\text {DEX }}$. In another set of experiments, iDC were matured with $2 \mu \mathrm{g} / \mathrm{mL}$ of peptidoglycan (PGN) and $10 \mu \mathrm{g} / \mathrm{mL}$ of lipoteichoic acid (LTA, both from Invivogen, France).

\section{Phenotype analysis of MoDC by FACS}

Anti-human leukocyte antigen class II-APC-vio770 (MHC-II) (clone REA805), anti-CD1a PE-Vio770 ${ }^{\circledR}$ (clone REA736), anti-CD14 Vioblue ${ }^{\circledR}$ (clone REA599), anti-CD86 APC (clone: FM95), anti-CD83 Viobright ${ }^{\circledR}$ (clone REA714) and anti-CD11c PECy5 (clone: B-ly6) mAbs (All from Miltenyi Biotec except the CD11c from Becton Dickinson) were used for direct immunofluorescence staining to characterize the phenotype of DC generated in the indicated conditions. Briefly, collected cells were washed in phosphate-buffered saline (PBS) containing $10 \%$ human serum and were stained with indicated fluorescent labeled antibodies, plus a viability dye (Miltenyi Biotec) for $30 \mathrm{~min}$ at $4^{\circ} \mathrm{C}$. Cells were stained with isotype-matched control antibodies to evaluate nonspecific binding in parallel experiments. The cells were then washed and acquired using a MACSQuant ${ }^{\circledR}$ Analyzer 10 instrument (Miltenyi Biotec). Analysis was performed on gated population that excluded doublets and dead cells. Data were analyzed using FlowJo software version $\mathrm{X}$ 10.0.7.r2 (Tree Star).

\section{Cytokine quantitation}

$1 \times 10^{5}$ iDCs were matured with LPS (100 ng/mL) for $48 \mathrm{hrs}$ in their respective media: $\mathrm{R} 10_{\mathrm{ASW}} \mathrm{R} 10_{\mathrm{CTRL}}$ or $\mathrm{R} 10_{\mathrm{DEX}}$. Supernatants were collected and stored at $-80^{\circ} \mathrm{C}$. IL-10, IL-6, IL-12p70, IL-23 and TNF amounts were measured by a bead-based multiplex assay (LEGENDplex ${ }^{\mathrm{TM}}$, Biolegend) following the Manufacturer's recommendations. Flow cytometric analysis were performed with a MACSQuant ${ }^{\circledR}$ Analyzer 10 instrument (Miltenyi Biotec). Data were analyzed using FlowJo software version X 10.0.7.r2 (Tree Star).

\section{Allogeneic naive $\mathrm{CD}^{+} \mathrm{T}$ cell stimulation by MoDC}

Mixed lymphocyte reactions (MLRs) were performed in 96 wells round-bottom microtiter plates (Falcon 353 077) by adding 105 allogeneic naive $\mathrm{CD} 4^{+} \mathrm{T}$ cells to varying numbers of DCs in $200 \mu \mathrm{L}$ complete RPMI (RPMI 1640 Medium, supplemented with $10 \%$ FCS, $1 \%$ penicillin $(10,000 \mathrm{U} / \mathrm{mL})$ and streptomycin $(10 \mathrm{mg} / \mathrm{mL})$, Sodium pyruvate $(1 \mathrm{mmol} / \mathrm{L})$, HEPES (N-2-hydroxyethylpiperazine-N-2-ethane sulfonic acid, $10 \mathrm{mmol} / \mathrm{L}$ ) all from GIBCO and GlutaMAX ${ }^{\mathrm{TM}}$ (Invitrogen). In some experiments, $\mathrm{T}$ cells were previously stained with CTV (Thermofisher Scientific), according to the manufacturer's recommendations, in order to measure the proliferation by flow cytometry. Cultures were maintained for 5 days at $37^{\circ} \mathrm{C}$ in a $5 \% \mathrm{CO}_{2}$ humidified atmosphere. The proliferative response was measured after 5 days of culture by CTV dilution analysis by flow cytometry. Briefly, cells were harvested, washed with PBS-EDTA and stained with anti-CD4-PE (clone RPA-T4) and viability dye eFluor ${ }^{\mathrm{TM}} 780$ (eBioscience) for $30 \mathrm{~min}$ at $4^{\circ} \mathrm{C}$. Cells were washed with PBS-EDTA and analyzed by flow cytometry using a MACSQuant $^{\mathbb{B}}$ Analyzer 10 instrument (Miltenyi Biotec). In parallel experiments performed with unstained $\mathrm{T}$ cells at DC:T cell ratio 1:10, secreted cytokines (IL-4, IL-17, IL-22, TNF and IFN- $\gamma$ ) were quantified using a bead-based multiplex immunoassay (MACSPlex, Miltenyi Biotec) following the manufacturer's instructions. In parallel experiments performed with unstained $\mathrm{T}$ cells at DC:T cell ratio 1:10, cells were stimulated for $4 \mathrm{~h}$ with phorbol myristate acetate (PMA) (50 ng/ml; Sigma) and ionomycin $(500 \mathrm{ng} / \mathrm{ml}$; Sigma) in presence of GolgiPlug (BD Biosciences). Cells were next stained with anti-CD4-vioBlue antibody and viobility 405/520 fixable viability dye (Miltenyi Biotec) for $30 \mathrm{~min}$ at $4{ }^{\circ} \mathrm{C}$. Cells were next fixed with $4 \%$ PFA, permeabilized with 0,1\% Saponine (Sigma Aldrich) and then were incubated with anti-IFN- $\gamma$-APC, anti-IL-17-APCvio770, anti-IL-22-FITC and anti-IL-4-PEvio770 antibodies (Miltenyi Biotec) for $45 \mathrm{~min}$ at $4^{\circ} \mathrm{C}$. Cells were washed, and cytokine profiles were analyzed using a MACSQuant ${ }^{\mathbb{R}}$ Analyzer 10 instrument (Miltenyi Biotec); the data were analyzed using FlowJo software version X 10.0.7.r2 (Tree Star). The percentage of cytokine ${ }^{+}$cells was analyzed among viable $\mathrm{CD} 4^{+}$cells.

\section{Statistical analysis}

GraphPad Prism software (version 6; GraphPad Software, La Jolla, CA) was used. Means were compared between groups 
using One-way ANOVA (Dunnett's Multiple Comparison Test) or Friedman Test with Dunn's post hoc test.

\section{Results}

\section{ASW impairs MoDC differentiation and maturation}

To analyze the impact of ASW on DC functions, we generated monocyte-derived dendritic cells in ASW-based RPMI basal culture medium (Figure 1A). We first analyzed the effects of ASW on DC differentiation and maturation. $\mathrm{CD} 14^{+}$cells were differentiated into DCs with IL-4 and GM-CSF for five days in ASW-based or control water (CTW)-based medium or CTW-based medium plus dexamethasone (inhibits DC differentiation and maturation). Loosely adherent cells were next harvested and DC differentiation was assessed by analyzing the expression of CD11c by flow cytometry. More than $95 \%$ of the cells expressed CD11c in the three culture conditions tested (Figure 1A). We next evaluated whether ASW impacted the yield of iDC generated and we observed that the number of iDCs collected was similar in the ASW and CTW conditions while dexamethasone significantly decreased the number of iDCs obtained (Figure 1B). ASW is poorly mineralized and does not contains minerals expected to have an impact on cell viability (Table S1). Likewise, ASW-based medium did not present any cytotoxicity for DCs as measured with the viability dye by flow cytometry (Figure 1B). iDC were next treated with LPS for $48 \mathrm{~h}$ and tested for the expression of CD83, CD86, CD1a, HLA-DR and CD14. During the differentiation into DCs, monocytes are expected to lose CD14 and gain $\mathrm{CD} 1 \mathrm{a}$ expression. CD1a expression was significantly lower in $\mathrm{DC}$ matured with $\mathrm{ASW}$ ( $\left(\mathrm{DC}_{\mathrm{ASW}}\right)$ as compared to

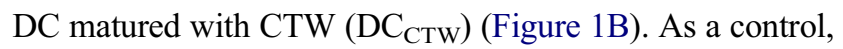
DC matured with CTW supplemented with dexamethasone $\left(\mathrm{DC}_{\mathrm{DEX}}\right)$ did not express CD1a and remained $\mathrm{CD} 14^{+}$. The joint analysis of CD86 and CD83 expression revealed that the proportion of fully mature $\mathrm{DCs}\left(\mathrm{CD} 86^{\text {high }} \mathrm{CD} 83^{\text {high }}\right)$ was significantly reduced among $\mathrm{DC}_{\mathrm{ASW}}$ as compared to $\mathrm{DC}_{\mathrm{CTW}}$ (Figure 1C). Accordingly, the expression of CD86 (gMFI fold increase over isotype control) was lower in $\mathrm{DC}_{\mathrm{ASW}}$ compared to $\mathrm{DC}_{\mathrm{CTW}}$ (Figure 1D). The three sets of DCs expressed HLA-DR on their surface and we observed a slight reduction of HLA-DR expression in $\mathrm{DC}_{\mathrm{ASW}}$ compared to $\mathrm{DC}_{\mathrm{CTW}}$ (Figure 1E). Because several Gram-positive bacteria are known to invade the skin, we also analyzed whether ASW impairs DC maturation induced by Gram-positive PAMPs such as peptidoglycan (PGN) and lipoteichoic acid
(LTA). Following maturation with LTA or PGN, $\mathrm{DC}_{\mathrm{ASW}}$ exhibited a reduced expression of CD1a compared to $\mathrm{DC}_{\mathrm{CTW}}$ (Figure 2).

Taken together, these results show that ASW reduces the expression of differentiation and maturation markers on the DC surface upon priming with LPS, PGN or LTA.

\section{DCs generated in ASW-based medium harbor a diminished ability to prime naive $\mathrm{CD}^{+} \mathrm{T}$ cells}

Upon maturation with LPS, DCs are expected to acquire the ability to efficiently prime naive allogeneic-CD $4^{+} \mathrm{T}$ cells. We therefore examined the capacity of $\mathrm{DC}_{\mathrm{ASW}}$ to prime and activate $\mathrm{T}$ cells. We co-cultured $\mathrm{DC}_{\mathrm{ASW}}$ or control $\mathrm{DCs}$ $\left(\mathrm{DC}_{\mathrm{CTW}}\right.$ and $\left.\mathrm{DC}_{\mathrm{DEX}}\right)$ with sort-purified and CTV-labelled naive $\mathrm{CD} 4^{+} \mathrm{T}$ cells from allogeneic healthy donors at different ratios. After 5 days of co-culture, $\mathrm{CD}^{+} \mathrm{T}$ cell proliferation was measured by flow cytometry analysis of CTV dilution. We observed that $\mathrm{DC}_{\mathrm{ASW}}$ induced a smaller fraction of naive $\mathrm{CD}^{+} \mathrm{T}$ cells to proliferate compared to $\mathrm{DC}_{\mathrm{CTW}}$, regardless of the $\mathrm{T}$ cell:DC ratio. As expected, control $\mathrm{DC}_{\mathrm{DEX}}$ barely induced $\mathrm{CD} 4{ }^{+} \mathrm{T}$ cell proliferation (Figure 3 ).

\section{ASW decreases the amount of IL- 12 and IL-23 and augments the amount of IL- 10 produced by DCs upon LPS-induced}

\section{maturation}

Upon maturation, DCs produce a panel of cytokines that participate to inflammation and orient $\mathrm{T}$ helper cell responses. ${ }^{12}$ We first analyzed the impact of ASW on cytokine production by DCs upon maturation induced by LPS. DCs cultured either with ASW-Based or CTW-based culture media were tested for IL-12p70, IL-23, IL-6, IL-10 and TNF production by the collection of cell-free culture supernatant $48 \mathrm{hrs}$ after LPS stimulation. As shown in Figure $4, \mathrm{DC}_{\mathrm{ASw}}$ produced smaller amounts of IL- $12 \mathrm{p} 70$ and IL-23 but higher amount of IL-10 as compared to $\mathrm{DC}_{\mathrm{CTW}}$. By contrast, TNF production was not affected and IL-6 production was barely impacted by ASW.

\section{$\mathrm{CD}^{+} \mathrm{T}$ cells differentiated with $\mathrm{DC}_{\mathrm{ASW}}$ show a reduced production of IFN- $\gamma$ and IL-I7}

We next investigated the abilities of $\mathrm{DC}_{\mathrm{ASW}}, \mathrm{DC}_{\mathrm{CTW}}$ and $\mathrm{DC}_{\mathrm{DEX}}$ to drive $\mathrm{CD} 4^{+} \mathrm{T}$ cells differentiation by measuring the IL-4, IL-17, TNF, IL-22 and IFN- $\gamma$ production by 

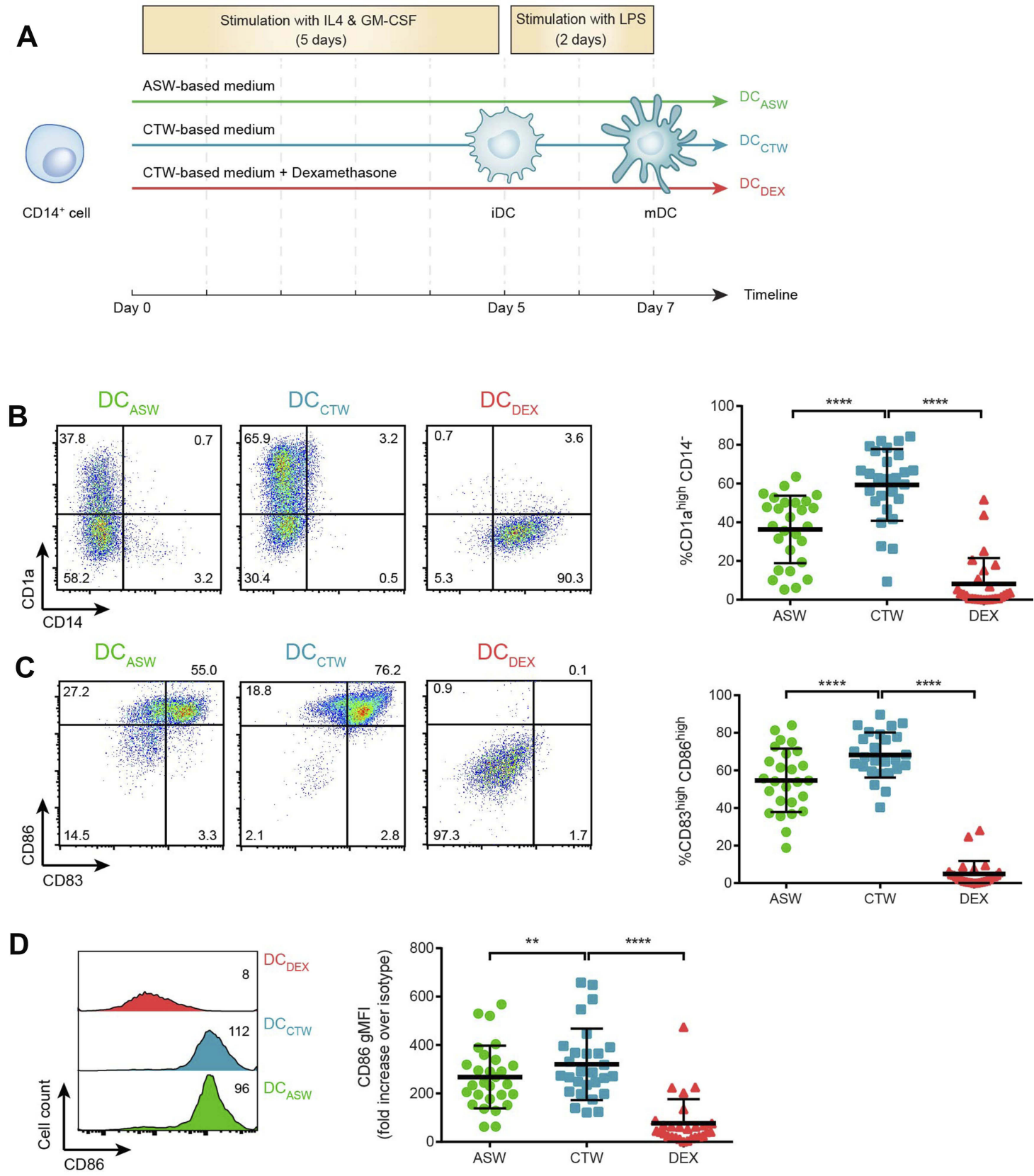

$\mathbf{E}$
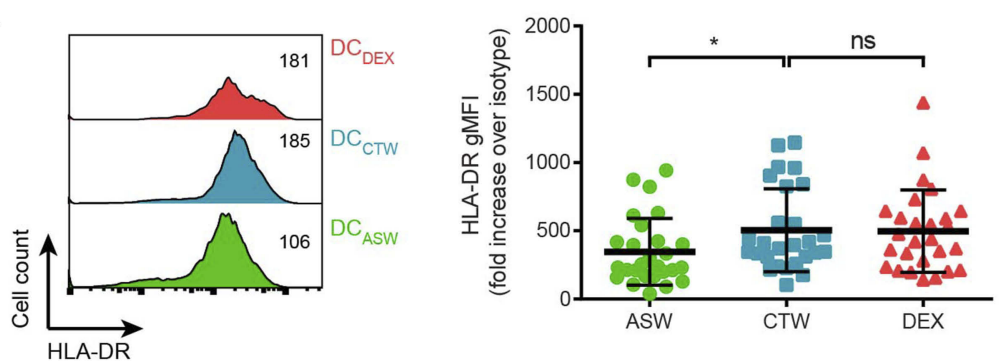

Figure I ASW impairs DC differentiation and maturation following LPS stimulation. Expression of CDI4, CDIa, CD83, CD86, and HLA-DR on DCs matured with LPS. (A) DC generation and priming protocol. (B-C) Representative dot plots of CDI a and CDI4 (B) or CD83 and CD86 (C) expression following maturation with LPS and pooled data from n=27 donors representing \% CDlahigh CDI4- cells (B) and \% CD86highCD83high cells (C), Quadrant were set to delimit CDI4 expression and CD lahigh or CD83high or CD86high expressions. Numbers indicate the percentage of cells in each quadrant. (D-E) Representative histograms of CD86 (D) and HLA-DR (E) expression following maturation with LPS (numbers indicate $\mathrm{gMFI}$ ) and pooled data from $\mathrm{n}=27$ donors (gMFI fold increase over the isotype control). Each point represents a donor, bars indicate the mean \pm SD. Oneway ANOVA (Dunnett's multiple comparison test) (B-D); Friedman's test with Dunn's post hoc test (E). ${ }^{*} p<0.05$; ${ }^{* *} p<0.01$; ${ }^{* * * * *} p<0.000$ I; ns, not significant.

Abbreviations: ASW, Avène thermal spring water; DC, dendritic cell; CTW, control water; DEX, dexamethasone. 

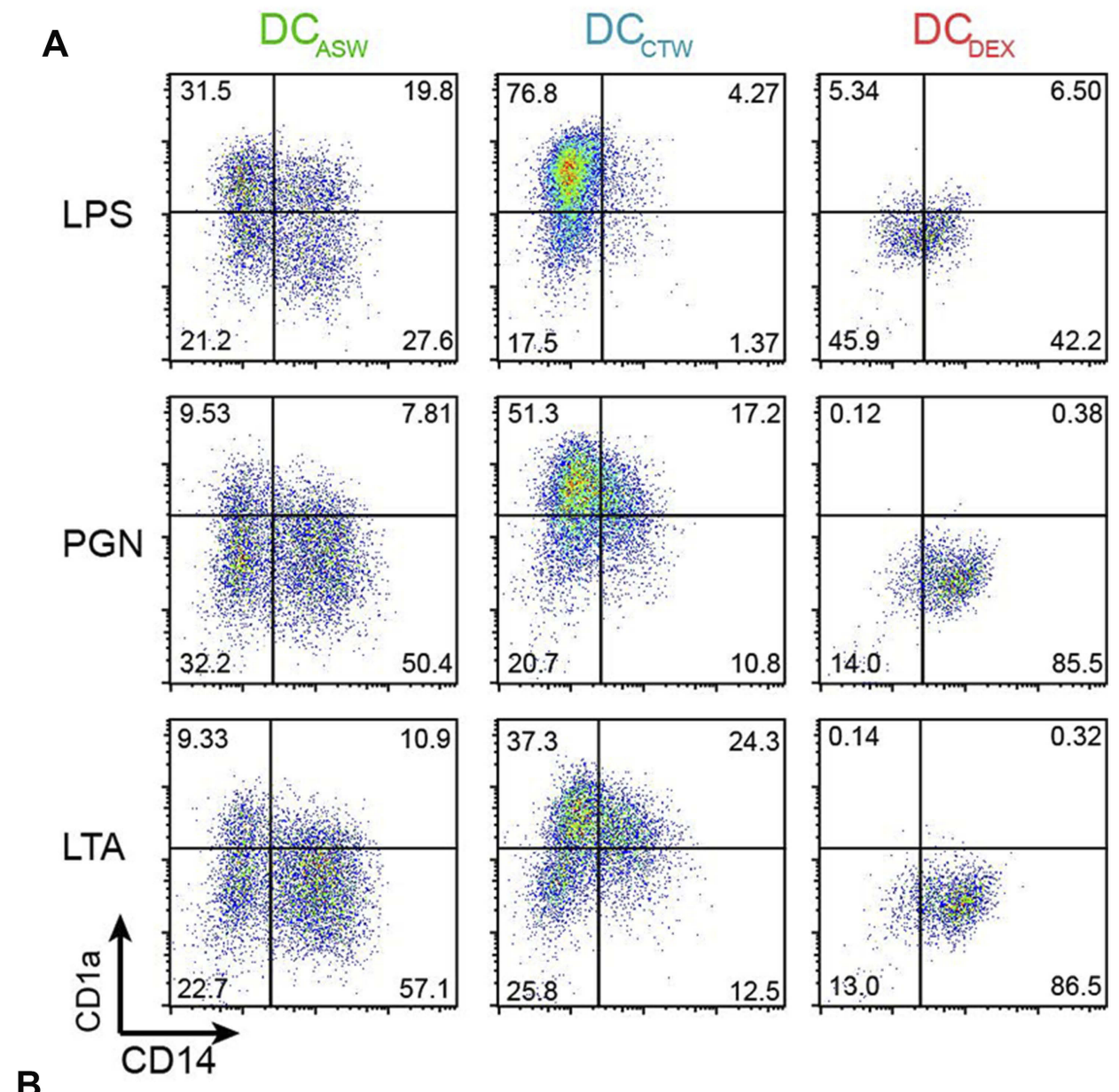

B
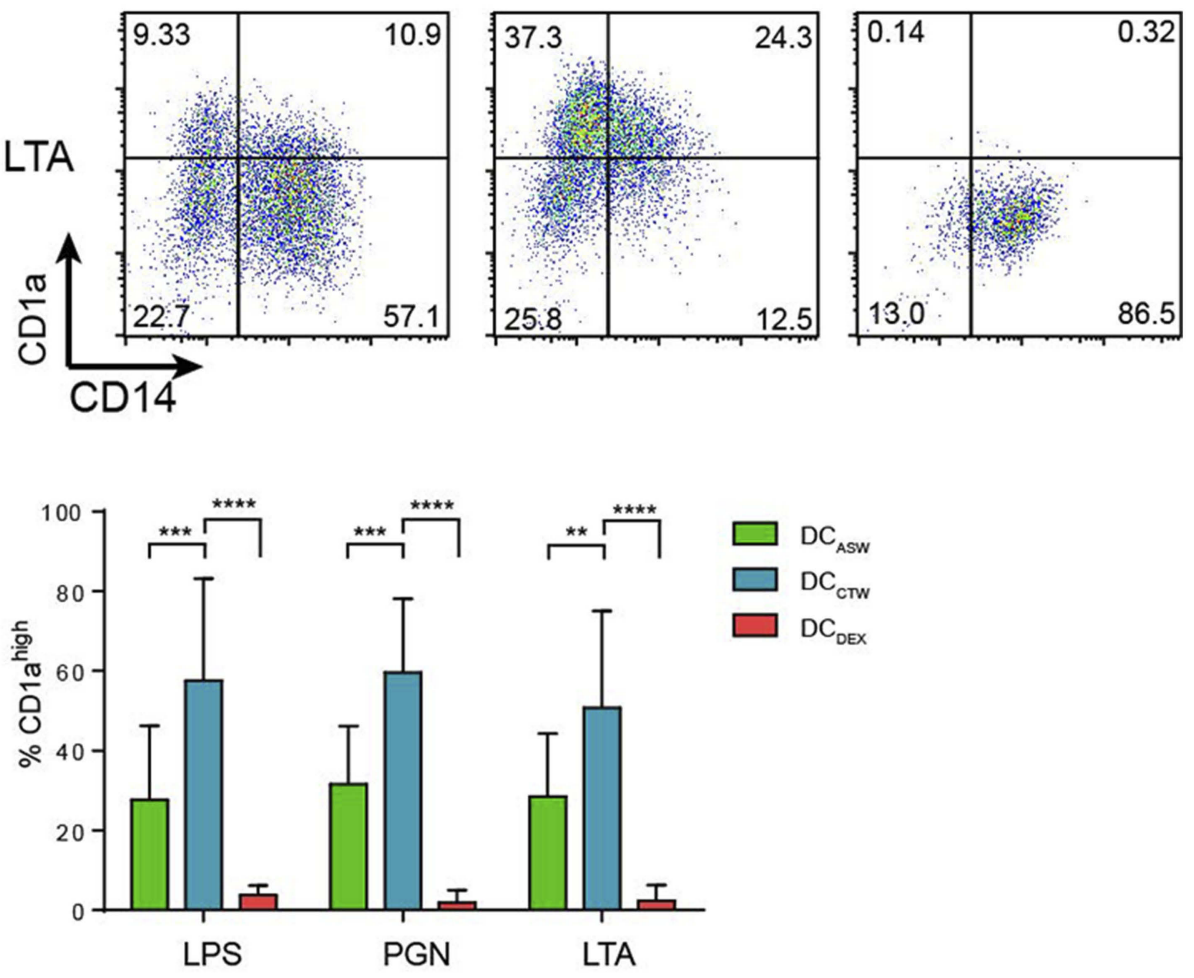

Figure 2 ASW impairs DC differentiation and maturation induced by different PAMPs. Expression of CDI4 and CDIa on the surface of DCs matured with LPS or LTA or PGN. (A) Representative dot plots of CDIa and CDI4. Quadrant were set to delimit CDI4 expression and CDIahigh expression. Numbers in the quadrants indicate percentages. (B) Pooled data from $n=7$ donors (mean \pm SD). Two-way ANOVA (Dunnett's multiple comparison test). $* * p<0.0 \mathrm{I}$; $* * * p<0.00 \mathrm{I} ; * * * p<0.000 \mathrm{I}$. Abbreviations: ASW, Avène thermal spring water; DC, dendritic cell; LTA, lipoteichoic acid; PGN, peptidoglycan; CTW, control water; DEX, dexamethasone.

$\mathrm{CD}^{+} \mathrm{T}$ cells in the co-culture supernatants. IL-4, IL-17 and IL-22 were not detected for almost all the donors tested (data not shown). The amount of IFN- $\gamma$ produced was lower with $\mathrm{DC}_{\mathrm{ASW}}$ as compared to $\mathrm{DC}_{\mathrm{CTW}}$ (Figure $5 \mathrm{~A})$. By contrast, TNF production was not statistically different between cocultures with $\mathrm{DC}_{\mathrm{ASW}}$ and $\mathrm{DC}_{\mathrm{CTW}}$, only cocultures with $\mathrm{DC}_{\mathrm{DEX}}$ exhibited a decreased $\mathrm{TNF}$ production (Figure 5B).

We also used flow cytometry to analyze intracellular cytokine expression in $\mathrm{CD}^{+} \mathrm{T}$ cells restimulated by PMA and ionomycine after 5 days of MLR. This readout allowed us to detect some $\mathrm{CD} 4^{+} \mathrm{T}$ cells producing IL-17 (Figure 5C). 


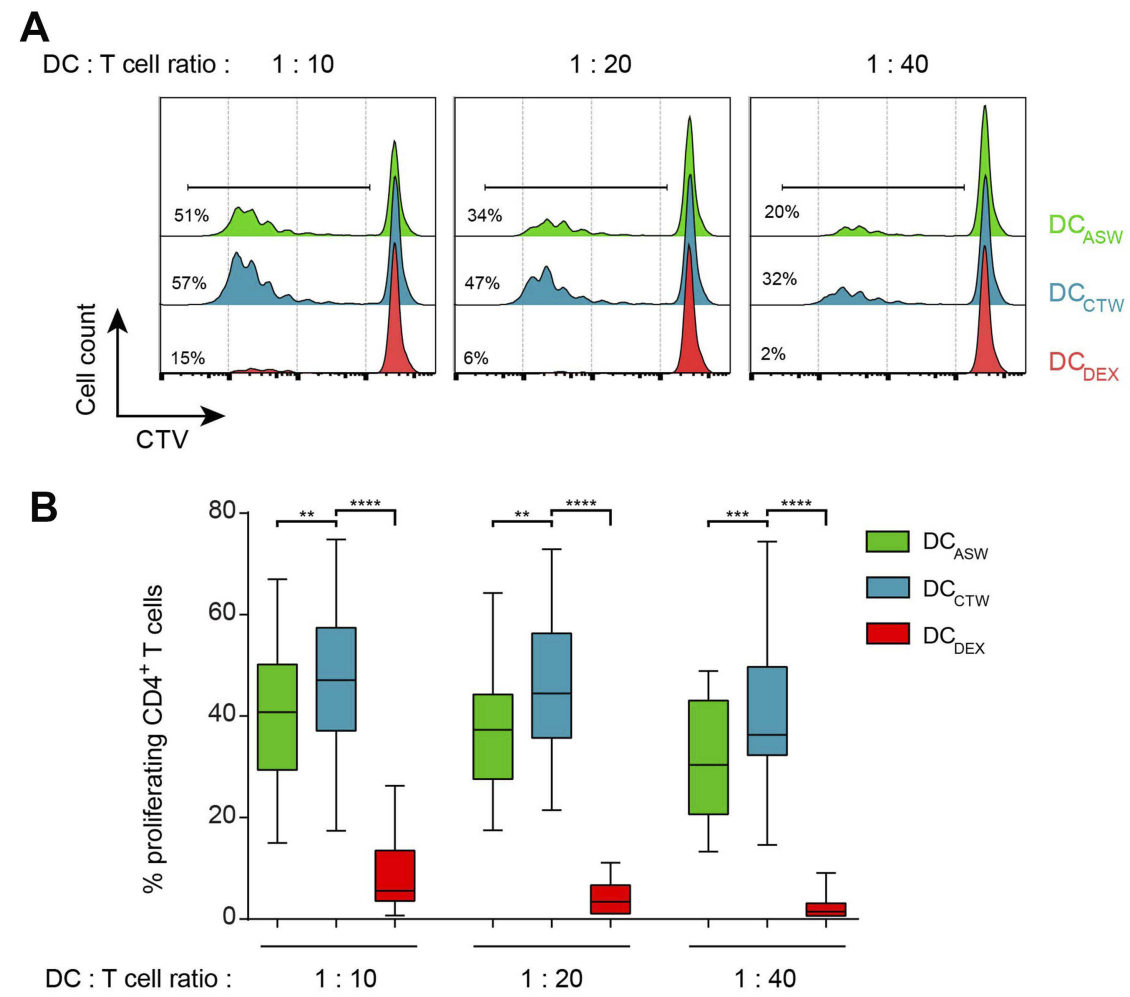

Figure $3 \mathrm{DC}_{\mathrm{Asw}}$ exhibit a reduced ability to induce CD4 ${ }^{+} \mathrm{T}$ cell proliferation. CTV-loaded allogeneic naive CD4 ${ }^{+} \mathrm{T}$ cells were cocultured with indicated DCs at T cell:DC ratio of I: 10, I:20 or I:40 for 5 days and CTV dilution was analyzed by flow cytometry in CD4 ${ }^{+} \mathrm{T}$ cells. (A) Representative histograms; numbers indicate the percentage of proliferating $\mathrm{CD}^{+} \mathrm{T}$ cells. (B) Pooled data from $\mathrm{n}=27$ donors, box and whiskers representation (minimum, first quartile, median, third quartile, and maximum). $* *<<0.01$, $*_{* *} p<0.001$, ***** $p<0.000$ I, One-way ANOVA (Dunnett's multiple comparison test).

Abbreviations: ASW, Avène thermal spring water; DC, dendritic cell; CTW, control water; DEX, dexamethasone; CTV, Celltrace violet.

ASW reduced slightly, but significantly the ability of $\mathrm{DC}_{\mathrm{ASW}}$ to induce IL-17 production by $\mathrm{CD} 4^{+} \mathrm{T}$ cells. $\mathrm{CD} 4^{+} \mathrm{T}$ cells producing IL-4 or IL-22 were observed only in a few donors, making statistical analysis impossible (data not shown). This analysis clearly showed that the percentage of $\mathrm{CD}^{+} \mathrm{T}$ cells producing IFN- $\gamma$ decreased when the $\mathrm{T}$ cells response was generated with $\mathrm{DC}_{\mathrm{ASW}}$ compared to $\mathrm{DC}_{\mathrm{CTW}}$ (Figure 5D).

\section{Discussion}

In this study, we analyzed the effects of ASW on DC differentiation, maturation and functions. We show that ASW dampens DC differentiation and maturation and decreases their ability to elicit inflammatory $\mathrm{T}$ helper cell responses in MLR.

ASW is poorly mineralized $(266 \mathrm{mg} / \mathrm{L})$ and characterized by a significant amount of silicates, a low sodium concentration, a calcium/magnesium ratio of 1:2, and a high diversity of trace elements (Table S1). ${ }^{28}$ Moreover, ASW contains organic compounds derived from microorganisms such as Aquaphilus dolomiae. ${ }^{28-30}$ Prolonged exposure to spring water during spa is expected to allow these compounds to permeate into the skin. We sought to analyze the impact of ASW on the immune response. Because DCs are crucial for the induction and the control of immune responses, we investigated the effect of thermal spring water on DC differentiation, maturation and functions.

To assess the impact of ASW on DCs, we generated monocyte-derived DCs, the gold standard in vitro model for DCs. Monocytes cultured for 5 days in presence of GMCSF and IL- ${ }^{31}$ resemble immature myeloid dendritic cells. ${ }^{32}$ These iDC matured with LPS or inflammatory cytokines are close to in vivo inflammatory DCs. ${ }^{15,33-35}$ Since monocytes that infiltrate inflamed tissues are expected to differentiate and maturate in a continuous process, we analyzed the effects of ASW on both steps of differentiation and LPS-induced maturation (Figure 1A), by including this water in the composition of the culture medium. Ultra-pure commercial distilled water, with or without dexamethasone, were used as experimental controls.

When monocytes are differentiated into iDCs, they are expected to upregulate MHC class II molecules and CD1a at the same time, while losing CD14 molecules expression. ${ }^{32}$ Upon maturation with LPS, iDCs upregulate costimulation molecules such as CD80 and CD86. ${ }^{32}$ We observed that ASW induced significant changes in the phenotype of 
A
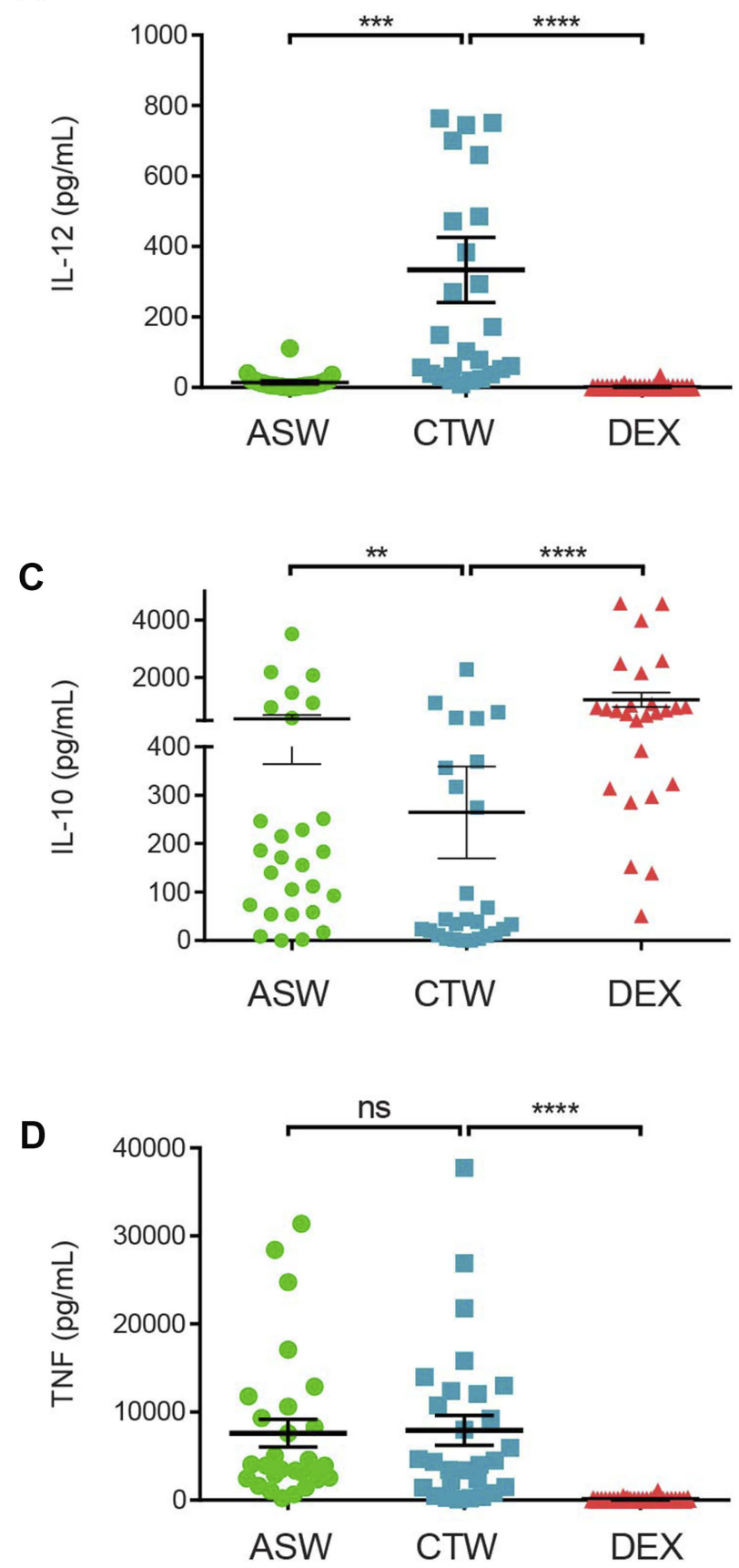

B

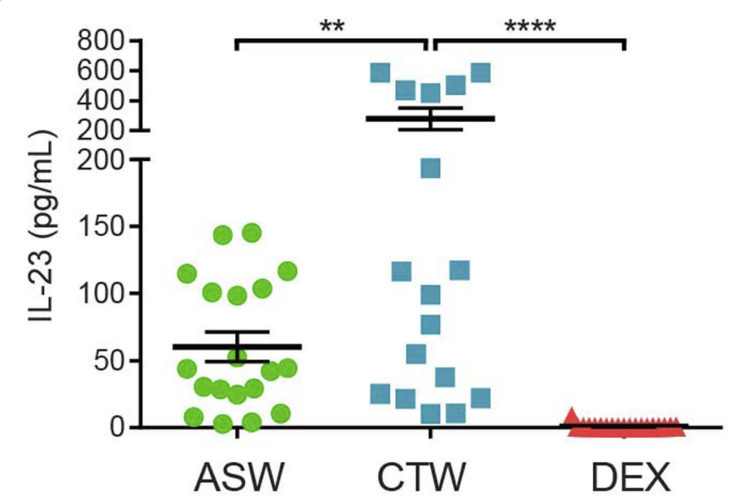

Figure $4 \mathrm{DC}_{\mathrm{ASW}}$ show a reduced ability to produce IL-12 and IL-23 but an increased ability to produce IL- I0. Production of IL-I2p70 (A), IL-23 (B), IL- I0 (C), TNF (D) and IL-6 (E) by DC matured with LPS in indicated conditions. Cytokines were measured by multiplex assay. Each point represents a donor, bars indicate the mean \pm SD. One-way ANOVA (Dunnett's multiple comparison test) (B, E) Friedman's test with Dunn's post hoc test (A,C,D) $*_{p}<0.05 ; * *_{p}<0.01$; $* * * p<0.00$ I; $* * * *<<0.000$ I; ns, not significant. Abbreviations: ASW, Avène thermal spring water; DC, dendritic cell; CTW, control water; DEX, dexamethasone.

LPS-matured DCs. CD1a expression was highly variable among individuals (Figure 1B) as previously reported by Cernadas et al. $^{36}$ Nevertheless, by testing DCs generated from a large number of donors $(n=27)$, we clearly showed that CD1a expression was strongly reduced by ASW. The main role of CD1a is to present lipid or glycolipid antigens to
T cells, but it also appears as a marker of monocyte to DC differentiation because it is principally induced during the differentiation step. ${ }^{37}$ Different studies have compared the $\mathrm{CD} \mathrm{a}^{+}$and $\mathrm{CD} 1 \mathrm{a}^{-}$populations of MoDC and showed that $\mathrm{CD} \mathrm{a}^{+}$are more prone to produce IL-12 and polarize $\mathrm{CD} 4^{+}$ T cells toward a Th1 phenotype. ${ }^{36,37}$ Moreover CD1a ${ }^{+} \mathrm{MoDC}$ 
A

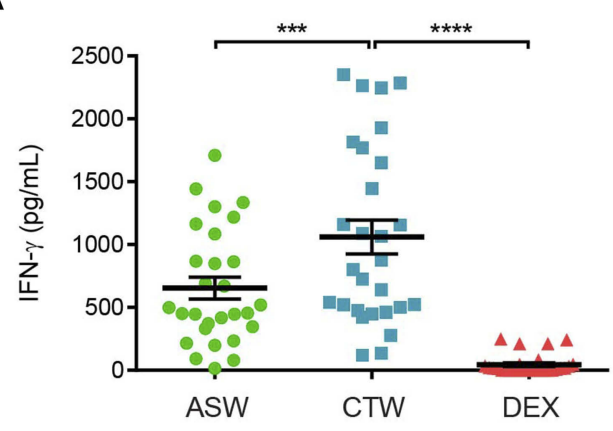

C

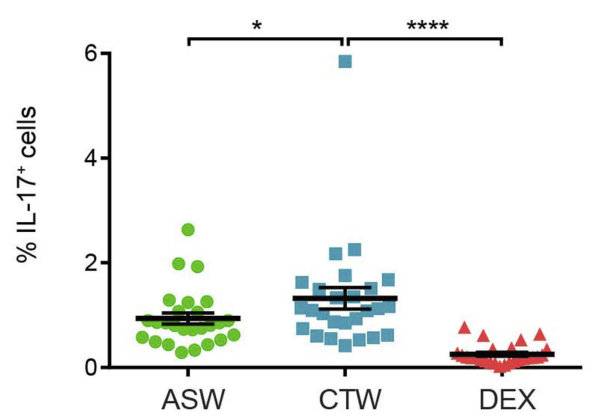

B

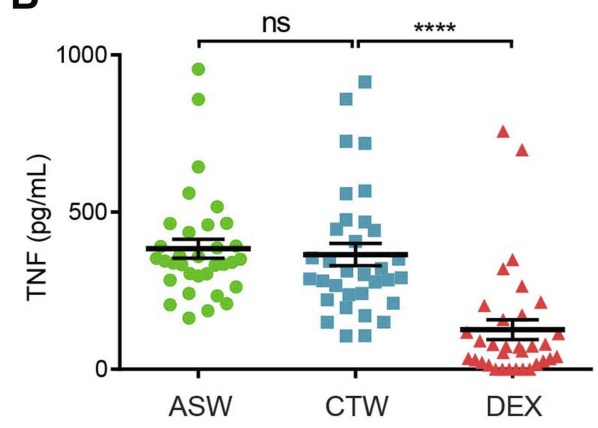

D

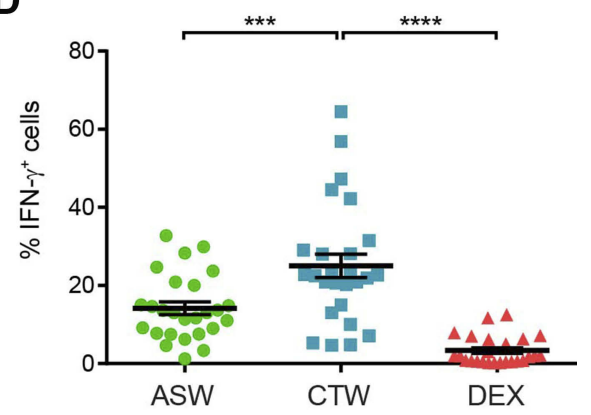

Figure $5 \mathrm{CD}^{+}$T cells stimulated with $\mathrm{DC}_{\mathrm{ASW}}$ exhibit a reduced ability to produce IFN- $\gamma$. (A,B) Amount of IFN- $\gamma(\mathbf{A})$ or TNF (B) measured in the supernatant of CD4 $4^{+} \mathrm{T}$ cell co-cultures in indicated conditions. (C-D) Percentage of IL- $17^{+} \mathrm{CD} 4^{+} \mathrm{T}$ cells (C) and IFN- $\gamma^{+} \mathrm{CD} 4^{+} \mathrm{T}$ cells (D) following restimulation with PMA and ionomycine after 5 days of coculture. Each point represents an experiment ( $n=14$ donors, 2 independent experiments). Bars indicate the mean \pm SD. One-way ANOVA (Dunnett's multiple comparison test). $* p<0.05 ; * * * p<0.001$; $* * * *<<0.0001$; ns, not significant.

Abbreviations: ASW, Avène thermal spring water; DC, dendritic cell; CTW, control water; DEX, dexamethasone.

exhibited a more differentiated phenotype than their $\mathrm{CD} 1 \mathrm{a}^{-}$ counterparts. ${ }^{38}$ In agreement with these reports, our results show that a reduced expression of $\mathrm{CD} 1 \mathrm{a}$ in $\mathrm{DC}_{\mathrm{ASw}}$ is associated with a lower production of IL-12 and a reduced ability to generate Th1 cells. In light of these results, ASW dampens DC differentiation and limits their capacity to induce inflammatory $\mathrm{T}$ cell responses. In addition to LPS, we also tested PAMPs from Gram positive bacteria, to mature DCs in parallel experiments. We observed that ASW decreased the CD1a expression in DCs matured in presence of LTA or PGN. These results indicate that ASW seems to decrease DC maturation regardless of the priming stimulus.

Besides CD1a, ASW reduced the expression of the DC maturation markers CD86, CD83 and HLA-DR upon LPS stimulation. CD83 is mainly known as a marker of mature $\mathrm{DC}^{39}$ while CD86 and HLA-DR are key molecules for $\mathrm{CD} 4^{+} \mathrm{T}$ cell activation. Again, we observed a large variability of responses among the donors and a significant reduction of the maturation of $\mathrm{DC}_{\mathrm{ASW}}$ compared to the negative control

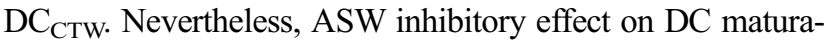
tion was not as effective as the dexamethasone-treatment excepted for HLA-DR expression. We observed that dexamethasone did not impact HLA-DR expression in agreement with previous reports. ${ }^{40,41}$ In order to determine whether ASW was able to impair the main function of DCs (i.e to induce naive $T$ cell activation) we tested the stimulatory capacity of $\mathrm{DC}_{\mathrm{ASW}}$ in MLR. We observed that ASW reduced the ability of the DCs to induce allogeneic naive $\mathrm{CD}^{+} \mathrm{T}$ cell proliferation. Naive $\mathrm{CD}^{+} \mathrm{T}$ cells are indeed tightly dependent on the costimulatory signals to be activated and we can speculate that the semi immature phenotype of DCs induced by ASW is responsible for their reduced ability to drive naive $\mathrm{CD}^{+} \mathrm{T}$ cell proliferation.

During cognate interaction with $\mathrm{CD} 4^{+} \mathrm{T}$ cells, DCs produce cytokines such as IL-12, IL-23, IL-10 or IL-6 that drive T helper cell differentiation. ${ }^{12}$ Hence, we evaluated the effects of ASW on cytokine production by DCs after the maturation step. We observed that DCs generated from some donors were not able to produce IL-12 nor IL-23 in response to LPS. Concerning DCs that are able to produce IL-12 or IL-23 in response to LPS, we observed a strong reduction of IL-12 production and a slight decrease of IL-23 production in $\mathrm{DC}_{\mathrm{ASW}}$. Because IL-12 and IL-23 drive Th1 and Th17 cell 
differentiation respectively, we analyzed the production of IFN- $\gamma$ and IL-17 by CD4 ${ }^{+}$T cell generated in the MLRs. We observed a significant reduction of IFN- $\gamma$ production and IFN$\gamma^{+} \mathrm{CD}^{+} \mathrm{T}$ cells, indicating that $\mathrm{DC}_{\mathrm{ASW}}$ have a reduced ability to drive Th1 responses. We were not able to detect IL-17 production by bead-based multiplexed assay in all the conditions tested, but we observed a decrease in the $\% \mathrm{IL}-17^{+} \mathrm{CD} 4^{+}$ $\mathrm{T}$ cells generated with $\mathrm{DC}_{\mathrm{ASW}}$ as compared to $\mathrm{DC}_{\mathrm{CTW}}$. This low percentage of $\mathrm{CD}^{+}{ }^{+} \mathrm{T}$ cells producing $\mathrm{IL}-17$, is consistent with reports in the literature ${ }^{42}$ and can be explained by the fact that we only used LPS as a stimulus for DC maturation. LPS is known to promote IL-12 production by DCs and thereby to drive mainly Th1 response, whereas LPS alone is a poor inductor of $\mathrm{IL}-23^{43}$ and therefore of Th17 response. It is noteworthy that TNF production in the supernatant of the MLR was similar with $\mathrm{DC}_{\mathrm{ASW}}$ and $\mathrm{DC}_{\mathrm{CTW}}$. TNF can be produced by DCs and by a large part of activated $\mathrm{CD}^{+} \mathrm{T}$ cells, without being limited to a defined Th subset.

Moreover, we showed that ASW did not impact TNF production and slightly reduced IL-6 production by DCs upon LPS-induced maturation. Interestingly, $\mathrm{DC}_{\mathrm{ASW}}$ exhibited an increased production of IL-10 as compared to $\mathrm{DC}_{\mathrm{CTW}}$. As expected, the IL-10 production was the highest with dexamethasone treatment. ${ }^{40}$ IL-10 is an inhibitory cytokine, that can be produced by virtually all the leukocytes. The main role of IL-10 is to limit the extent of the immune response, in order to protect the host against excessive immune reaction associated with infection, autoimmunity, and allergy.

\section{Conclusion}

Collectively, these results indicate that ASW fine tunes DC maturation by decreasing their ability to produce some cytokines such as IL-12, IL-23 and to a lesser extent IL-6, by fostering IL-10 production without impacting TNF production. This ASW-induced DC phenotype and functions, indicate that ASW favors the generation of immunomodulatory DCs, which might explain the beneficial effects of ASW-based hydrotherapy in the treatment of inflammatory skin diseases. It is tempting to speculate that ASW properties might rely on microbial molecules from endemic bacteria found in this thermal water, such as Aquaphilus dolomiae that was shown to promote IL-10 production and reduce $\mathrm{CD} 4^{+} \mathrm{T}$ cell activation by DCs. ${ }^{30}$

\section{Ethics approval and informed consent}

Buffy coats from healthy donors were obtained through the Etablissement Français du Sang (EFS Midi-Pyrénées,
Purpan University Hospital, Toulouse, France) and processed following standard ethical procedures (Helsinki protocol), after obtaining written informed consent from each donor and approval by the local ethics committee (Comité de Protection des Personnes Sud-Ouest et Outremer II).

\section{Abbreviation list}

ASW, Avène thermal spring water; CTV, Celltrace violet; DC, dendritic cell; DEX, dexamethasone; iDC, immature dendritic cell; MLR, mixed lymphocyte reaction; MoDC, monocytederived dendritic cell; PAMP, pathogen-associated molecular pattern, PBMC, peripheral blood mononuclear cell.

\section{Acknowledgments}

This research was supported by INSERM (Institut national de la santé et de la recherche médicale) and by Pierre Fabre Dermo-Cosmétique (PFDC). The funding body had no role in the design and conduct of the study, data collection, data management, data analysis and interpretation, writing the manuscript, or decision to submit results.

\section{Author contributions}

All authors contributed to data analysis, drafting and revising the article, gave final approval of the version to be published, and agree to be accountable for all aspects of the work.

\section{Disclosure}

D.R and M-F.G are employees of Pierre Fabre DermoCosmétique. Y.E. reports grants from Laboratoires Pierre Fabre, during the conduct of the study. E.E. reports grants from Laboratoires Pierre Fabre, during the conduct of the study. He also received grants and personal fees from Laboratoires Pierre Fabre, outside the submitted work. The authors report no other conflicts of interest in this work.

\section{References}

1. Matz H, Orion E, Wolf R. Balneotherapy in dermatology. Dermatol Ther. 2003;16(2):132-140.

2. Valitutti S, Castellino F, Musiani P. Effect of sulfurous (thermal) water on T lymphocyte proliferative response. Ann Allergy. 1990;65(6):463-468.

3. Celerier P, Richard A, Litoux P, Dreno B. Modulatory effects of selenium and strontium salts on keratinocyte-derived inflammatory cytokines. Arch Dermatol Res. 1995;287(7):680-682.

4. Bajgai J, Fadriquela A, Ara J, et al. Balneotherapeutic effects of high mineral spring water on the atopic dermatitis-like inflammation in hairless mice via immunomodulation and redox balance. $B M C$ Complement Altern Med. 2017;17(1):481.

5. Hahn HJ, Kim JS, Kim YH, Lee YB, Yu DS, Kim J-W. Investigation of immune-regulatory effects of mageumsan hot spring via protein microarray in vitro. Ann Dermatol. 2018;30(3):322-330. 
6. Lee H-P, Choi Y-J, Cho K-A, et al. Effect of spa spring water on cytokine expression in human keratinocyte hacat cells and on differentiation of CD4 ${ }^{+}$T cells. Ann Dermatol. 2012;24(3):324-336.

7. Zoller N, Valesky E, Hofmann M, et al. Impact of different spa waters on inflammation parameters in human keratinocyte $\mathrm{HaCaT}$ cells. Ann Dermatol. 2015;27(6):709-714.

8. Portales P, Aries MF, Licu D, et al. Immunomodulation induced by avene spring water on Th1- and Th2-dependent cytokine production in healthy subjects and atopic dermatitis patients. Skin Pharmacol Appl Skin Physiol. 2001;14(4):234-242.

9. Joly F, Charveron M, Aries MF, et al. Effect of Avene spring water on the activation of rat mast cell by substance P or antigen. Skin Pharmacol Appl Skin Physiol. 1998;11(2):111-116.

10. Banchereau J, Steinman RM. Dendritic cells and the control of immunity. Nature. 1998;392(6673):245-252. doi:10.1038/32588

11. Collin M, McGovern N, Haniffa M. Human dendritic cell subsets. Immunology. 2013;140(1):22-30. doi:10.1111/imm.12117

12. Kapsenberg ML. Dendritic-cell control of pathogen-driven T-cell polarization. Nat Rev Immunol. 2003;3(12):984-993. doi:10.1038/nri1246

13. Banchereau J, Briere F, Caux C, et al. Immunobiology of dendritic cells. Annu Rev Immunol. 2000;18:767-811. doi:10.1146/annurev. immunol.18.1.767

14. Walsh KP, Mills KHG. Dendritic cells and other innate determinants of T helper cell polarisation. Trends Immunol. 2013;34(11):521-530. doi:10.1016/j.it.2013.07.006

15. Kashem SW, Haniffa M, Kaplan DH. Antigen-Presenting Cells in the Skin. Annu Rev Immunol. 2017;35(1):469-499. doi:10.1146/annurevimmunol-051116-052215

16. Clausen BE, Stoitzner P. Functional specialization of skin dendritic cell subsets in regulating $\mathrm{T}$ cell responses. Front Immunol. 2015;6:534. doi:10.3389/fimmu.2015.00534

17. Chu -C-C, Di Meglio P, Nestle FO. Harnessing dendritic cells in inflammatory skin diseases. Semin Immunol. 2011;23(1):28-41. doi:10.1016/j.smim.2011.01.006

18. Zaba LC, Krueger JG, Lowes MA. Resident and "inflammatory" dendritic cells in human skin. J Invest Dermatol. 2009;129(2):302308. doi:10.1038/jid.2008.225

19. Coquerelle C, Moser M. DC subsets in positive and negative regulation of immunity. Immunol Rev. 2010;234(1):317-334. doi:10.1111/ j.0105-2896.2009.00887.x

20. Wakim LM, Waithman J, van Rooijen N, Heath WR, Carbone FR. Dendritic cell-induced memory T cell activation in nonlymphoid tissues. Science. 2008;319(5860):198-202. doi:10.1126/science.1151869

21. Lowes MA, Chamian F, Abello MV, et al. Increase in TNF- $\alpha$ and inducible nitric oxide synthase-expressing dendritic cells in psoriasis and reduction with efalizumab (anti-CD11a). Proc Natl Acad Sci U S A. 2005;102(52):19057-19062. doi:10.1073/pnas.0509736102

22. Hansel A, Gunther C, Ingwersen J, et al. Human slan (6-sulfo LacNAc) dendritic cells are inflammatory dermal dendritic cells in psoriasis and drive strong $\mathrm{T}(\mathrm{H}) 17 / \mathrm{T}(\mathrm{H}) 1 \mathrm{~T}$-cell responses. J Allergy Clin Immunol. 2011;127(3):787-U456. doi:10.1016/j.jaci.2010.12.009

23. Serbina NV, Salazar-Mather TP, Biron CA, Kuziel WA, Pamer EG. TN/iNOS-producing dendritic cells mediate innate immune defense against bacterial infection. Immunity. 2003;19(1):59-70.

24. Wollenberg A, Kraft S, Hanau D, Bieber T. Immunomorphological and ultrastructural characterization of Langerhans cells and a novel, inflammatory dendritic epidermal cell (IDEC) population in lesional skin of atopic eczema. J Invest Dermatol. 1996;106(3):446-453.

25. Raker VK, Domogalla MP, Steinbrink K. Tolerogenic dendritic cells for regulatory T cell induction in man. Front Immunol. 2015;6:569. doi:10.3389/fimmu.2015.00569

26. Naranjo-Gómez M, Raïch-Regué D, Oñate C, et al. Comparative study of clinical grade human tolerogenic dendritic cells. J Transl Med. 2011;9(1):89. doi:10.1186/1479-5876-9-89
27. Navarro-Barriuso J, Mansilla MJ, Martínez-Cáceres EM. Searching for the transcriptomic signature of immune tolerance inductionbiomarkers of safety and functionality for tolerogenic dendritic cells and regulatory macrophages. Front Immunol. 2018;9:2062.

28. Guerrero D, Garrigue E. Annales de dermatologie et de venereologie. Eau thermale d'Avène et dermatite atopique: Avène's thermal water and atopic dermatitis. 2017;144(Suppl 1):S27-s34. doi:10.1016/ S0151-9638(17)31040-2

29. Aries MF, Hernandez-Pigeon $\mathrm{H}$, Vaissiere C, et al. Anti-inflammatory and immunomodulatory effects of Aquaphilus dolomiae extract on in vitro models. Clin Cosmet Investig Dermatol. 2016;9:421-434. doi:10.2147/CCID.S113180

30. Martin H, Laborel-Preneron E, Fraysse F, et al. Aquaphilus dolomiae extract counteracts the effects of cutaneous $\mathrm{S}$. aureus secretome isolated from atopic children on CD4(+) T cell activation. Pharm Biol. 2016;54(11):2782-2785. doi:10.3109/13880209.2016.1173069

31. Sallusto F, Lanzavecchia A. Efficient presentation of soluble antigen by cultured human dendritic cells is maintained by granulocyte/ macrophage colony-stimulating factor plus interleukin 4 and downregulated by tumor necrosis factor alpha. J Exp Med. 1994;179 (4):1109-1118. doi:10.1084/jem.179.4.1109

32. Palucka KA, Taquet N, Sanchez-Chapuis F, Gluckman JC. Dendritic cells as the terminal stage of monocyte differentiation. J Immunol. 1998;160(9):4587-4595.

33. Grassi F, Dezutter-Dambuyant C, McIlroy D, et al. Monocyte-derived dendritic cells have a phenotype comparable to that of dermal dendritic cells and display ultrastructural granules distinct from Birbeck granules. J Leukoc Biol. 1998;64(4):484-493. doi:10.1002/jlb.64.4.484

34. Cheong C, Matos I, Choi J-H, et al. Microbial stimulation fully differentiates monocytes to DC-SIGN/CD209(+) dendritic cells for immune T cell areas. Cell. 2010;143(3):416-429. doi:10.1016/j.cell.2010.09.039

35. Sander J, Schmidt SV, Cirovic B, et al. Cellular differentiation of human monocytes is regulated by time-dependent interleukin-4 signaling and the transcriptional regulator NCOR2. Immunity. 2017;47 (6):1051-1066.e1012.

36. Cernadas M, Lu J, Watts G, Brenner MB. CD1a expression defines an interleukin-12 producing population of human dendritic cells. Clin Exp Immunol. 2009;155(3):523-533.

37. Faivre V, Lukaszewicz AC, Alves A, Charron D, Payen D, Haziot A. Human monocytes differentiate into dendritic cells subsets that induce anergic and regulatory T cells in sepsis. PLoS One. 2012;7(10):e47209.

38. Gogolak P, Rethi B, Szatmari I, et al. Differentiation of CD1a ${ }^{-}$and $\mathrm{CD} \mathrm{a}^{+}$monocyte-derived dendritic cells is biased by lipid environment and PPAR $\gamma$. Blood. 2007;109(2):643-652.

39. Zhou LJ, Tedder TF. Human blood dendritic cells selectively express CD83, a member of the immunoglobulin superfamily. $J$ Immunol. 1995;154(8):3821-3835

40. Xia C-Q, Peng R, Beato F, Clare-Salzler MJ. Dexamethasone induces IL-10-producing monocyte-derived dendritic cells with durable immaturity. Scand J Immunol. 2005;62(1):45-54.

41. Boks MA, Kager-Groenland JR, Haasjes MSP, Zwaginga JJ, van Ham SM, Ten Brinke A. IL-10-generated tolerogenic dendritic cells are optimal for functional regulatory $\mathrm{T}$ cell induction - a comparative study of human clinical-applicable DC. Clin Immunol. 2012;142(3):332-342.

42. Bellanger AP, Pallandre JR, Borg C, Loeffert S, Gbaguidi-Haore H, Millon L. Human monocyte-derived dendritic cells exposed to microorganisms involved in hypersensitivity pneumonitis induce a Th1-polarized immune response. Clin Vaccine Immunol. 2013;20(8):1133-1142.

43. Napolitani G, Rinaldi A, Bertoni F, Sallusto F, Lanzavecchia A Selected Toll-like receptor agonist combinations synergistically trigger a T helper type 1-polarizing program in dendritic cells. Nat Immunol. 2005;6:769. 


\section{Supplementary materials}

Table SI Mineral composition of Avène spring water (cf ref. ${ }^{28}$ )

\begin{tabular}{|c|c|c|c|}
\hline Anions & $\mathrm{mg} / \mathrm{mL}$ & Oligoelements & $\mu g / m L$ \\
\hline $\mathrm{HCO}_{3}^{-}$ & 230 & $\mathrm{Ba}$ & 50 \\
\hline $\mathrm{SO}_{4}^{2-}$ & 14 & $\mathrm{Cu}$ & $<20$ \\
\hline $\mathrm{Cl}^{-}$ & $<5$ & $\mathrm{Cr}$ & $<10$ \\
\hline $\mathrm{NO}_{3}^{-}$ & 1.5 & $\mathrm{Al}$ & $<10$ \\
\hline $\mathrm{F}^{-}$ & $<0.2$ & Se & $<5$ \\
\hline $\mathrm{PO}_{4}{ }^{3-}$ & $<0.05$ & $\mathrm{Zn}$ & $<20$ \\
\hline $\mathrm{NO}_{2}^{-}$ & $<0.05$ & & \\
\hline Silicates & 14 & & \\
\hline Cations & $\mathrm{mg} / \mathrm{mL}$ & & \\
\hline $\mathrm{Ca}^{2+}$ & 41 & & \\
\hline $\mathrm{Mg}^{2+}$ & 22 & & \\
\hline $\mathrm{Na}^{+}$ & 4.6 & & \\
\hline $\mathrm{K}^{+}$ & $<1$ & & \\
\hline $\mathrm{Li}^{+}$ & $<0.02$ & & \\
\hline $\mathrm{Sr}^{2+}$ & 0.09 & & \\
\hline $\mathrm{Fe}^{2+}$ & $<0.02$ & & \\
\hline $\mathrm{Mn}^{2+}$ & $<0.05$ & & \\
\hline
\end{tabular}


A
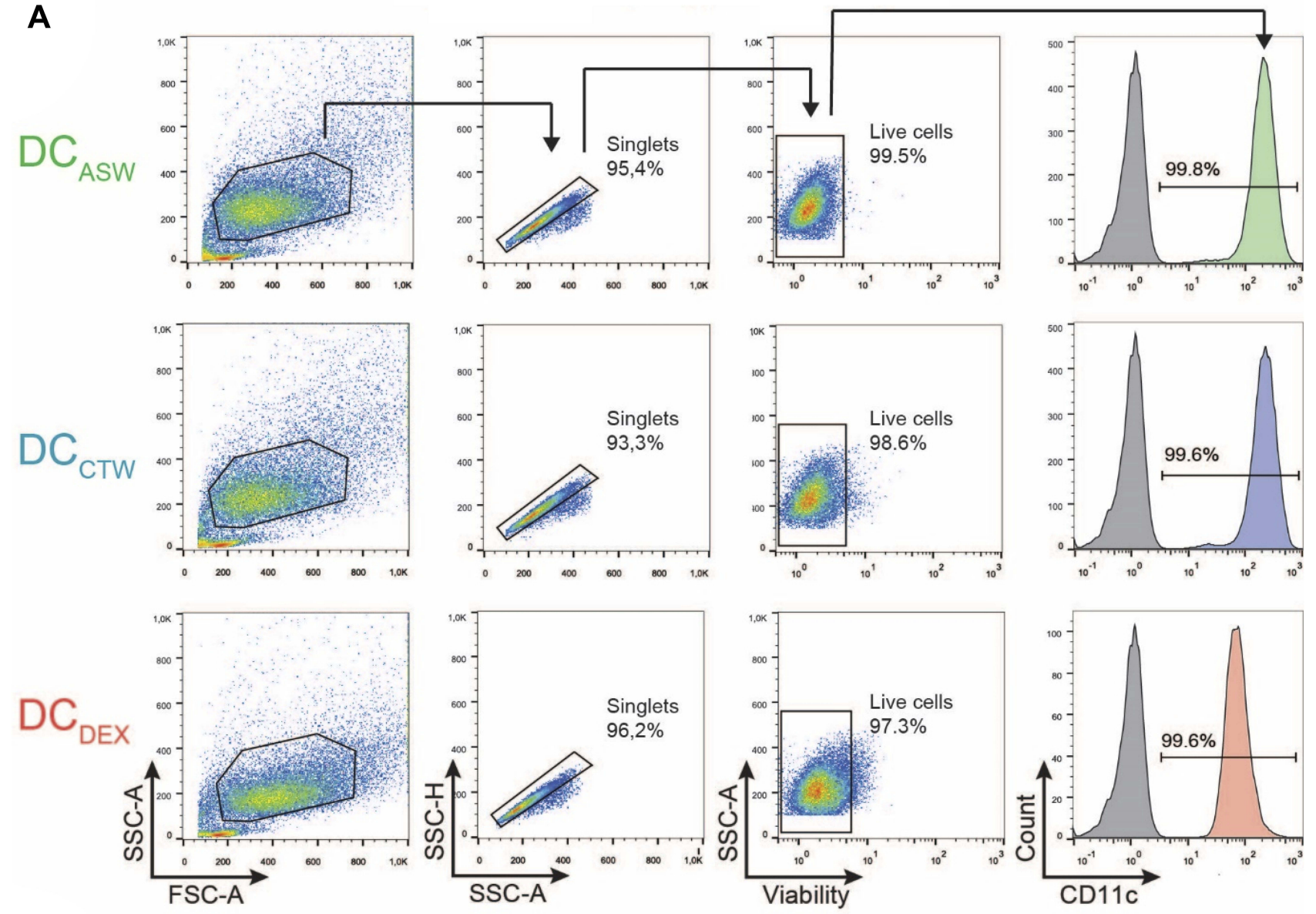

B

$\begin{array}{lcl}\text { Conditions } & \begin{array}{c}\text { iDCs collected } \\ \left(\times 10^{5} / \text { well }\right)\end{array} & \text { \% Live cells } \\ \mathrm{DC}_{\mathrm{ASW}}(\mathrm{n}=8) & 3.48 \pm 1.02 & 99.45 \pm 0.23 \\ \mathrm{DC}_{\mathrm{CTW}}(\mathrm{n}=8) & 4.88 \pm 1.94 & 99.50 \pm 0.31 \\ \mathrm{DC}_{\mathrm{DEX}}(\mathrm{n}=8) & 1.22 \pm 0.87 & 98.69 \pm 1.33\end{array}$

Total cell count values represent group mean $\pm S D$.

ASW, Avene Spring Water; CTW, Control Water; DEX, Control Water + Dexamethasone

Figure SI DCs generated in the three media tested. (A) CDIIc expression after the maturation step. Gating strategy and CDIIc fluorescence histograms. Grey histograms show cells stained with an irrelevant isotype-matched antibody. Numbers indicate the percentage of cells within the gate. (B) Number of iDC (loosely adherent cells) collected after the differentiation step and viability of DCs after the maturation step. 


\section{Publish your work in this journal}

The Journal of Inflammation Research is an international, peerreviewed open-access journal that welcomes laboratory and clinical findings on the molecular basis, cell biology and pharmacology of inflammation including original research, reviews, symposium reports, hypothesis formation and commentaries on: acute/chronic inflammation; mediators of inflammation; cellular processes; molecular

mechanisms; pharmacology and novel anti-inflammatory drugs; clinical conditions involving inflammation. The manuscript management system is completely online and includes a very quick and fair peerreview system. Visit http://www.dovepress.com/testimonials.php to read real quotes from published authors. 